\title{
Tender Coconut (Cocos nucifera L.) Husk Anaerobic Leachate as A Potent Antifungal and Antibacterial Agent
}

\author{
Praveen Krishnakumar* and Treesamol Antony
}

Immunology \& Toxicology Research Lab, Dept. of Zoology, Christ College, Irinjalakuda. Kerala, India.

\section{ABSTRACT}

Background: Leaching of tender coconut husk in anaerobic condition may leads to the production of a wide range of secondary metabolites including, alkaloids, terpenoids and phenolic compounds. In this study we have evaluated the antibacterial and antifungal potential of tender coconut husk leachate against Escherichia coli, Lactobacillus plantarum, Staphylococcus aureus, Klebsiella pneumoniae, Penicillium sps, Aspergillus niger and Mucor indicus.

Methods: Leachate was treated separately as unaltered raw leachate and lyophilized leachate.Qualitative phytochemical analysis of the tender coconut husk leachate was carried out using standard procedures. There are differences in the constituents present with raw and lyophilized leachate. Antibacterial activity were determined using disc diffusion method and also by calculating MIC and MBC. Antifungal activity was determined using poison plate method.

Result: Anaerobic leaching leads to the extraction of potent secondary metabolites which possess antibacterial and antifungal activities. Both the lyophilized and air dried raw leachate was effective in preventing the growth of gram negative bacteria (E.coli and K.pneumoniae) whereas the gram positive bacteria ( S.aureus and L.plantarum) were least affected.In higher concentrations leachate exhibited similar inhibitory activity as that of positive control used. We could also observe a concentration dependent growth inhibition in majority of the treatments.

Conclusion: From this study we could conclude that the anaerobic leachate of tender coconut husk exhibits antimicrobial activity against different pathogenic organisms. In all the trials the raw and lyophilized leachate showed very prominent control over both the bacteria and fungus studied. Further studies like specific characterization of potent molecules from the leachate and their action on multidrug resistant microorganisms are necessary todevelop effective and safe antimicrobial products.

Keywords: Phenolic Compounds, Antibacterial Activity, Antifungal Activity, Lyophilized Leachate, Raw Leachate.

\section{Introduction}

The wide varieties of plant products having ethnopharmacological importance have been used against many infectious and non-infectious diseases by traditional medical practitioners for thousands of years with or without proper scientific validation. Even though antibiotics are undisputedly considered as one of the important therapeutic discoveries of $20^{\text {th }}$ century, only one third of the infectious diseases known have been treated from this synthetic products[1].This implies the considerable increase in the rate of resistant pathogens against antibiotics. In general, bacteria have the genetic ability to transmit and acquire resistance to drugs, which are utilized as therapeutic agents. The resistance developed by many microbes against synthetic drugs was the major reason for switching over the search from synthetic chemicals to highly potent plant derived molecules which acts against a wide spectrum of microbes.

Fungi are among the important biotic agents which play a significant role in deteriorating aesthetic and nutritive value of the stored food commodity[2-3]. They are considered as significant destroyers of stored foodstuffs and grains, rendering them unfit for human consumption by retarding their nutritive value and often by producing mycotoxins[4-6]. A significant portion of the agricultural product in the country and the world over become unfit for human consumption due to mycotoxins contamination of grains, especially those produced by species of Aspergillus, Mucor and Penicillium.

Even though the precise mechanism of action of many plant extracts against bacteria is not well studied, but it has been proved that the stress and overload experienced by bacterial cell wall is the major reason behind bacteriostatic or bactericide activity[7]. This suggests that the action of same compound on gram positive and gram negative bacteria may vary considerably. Despite extensive progress in the past few years, the morbidity and mortality of invasive bacterial and fungal infections are still unacceptably high. It would therefore be novel to evaluate and identify antimicrobial drugs with new mechanisms of action having broad spectrum of activity, less toxicity, flexible route of administration. Current trends in drug development 
process are focused on natural sources, especially sources of plant origin due to some proven correlation between the folkloric medicinal uses of some of these plants to biological activity [8].

Coconut (Cocos nucifera L.) which comes under the family Arecaceae is commonly considered as an important fruit crop in tropical and subtropical countries. The coconut fruit comprises an outer epicarp, a mesocarp, and an inner endocarp. The mesocarp of coconut, commonly known as coconut "husk" is the major source of the coir fibre which is extracted from the husk by a process called as retting [9]. Retting of coconut husks encompasses the biodegradation of mainly polyphenols and pectins which play a major role in binding the fibre in the husk. Resorcinol, pyrogallolic acid and catechol were found to be major phenolic compounds leached out during retting of coconut husks.Cocos nucifera is a widely dispersed plant that has important pharmacological effects with low toxicity. Different constituents of endocarp and coconut water exhibit antioxidant activity whereas the fibre showed antibacterial, antiparasitic, and anti-inflammatory activities [10].

After scrutiny of published literature showing its medicinal importance as antioxidant, anthelminthic, antithrombotic, antimicrobial, antiatherosclerotic, immunostimulatory, antidiabetic, hepatoprotective andanticholecystitic effects the present study has been outlined regarding the antifungal and antibacterial activity of tender coconut husk leachate. Thus the aims of this study were 1.Anaerobic leaching of tender coconut husk, 2.Lyophilizing half of the extract obtained after leaching, 3.Qualitative phytochemical screening of anaerobic leachate, 4.To evaluate the antibacterial and antifungal activity of unaltered raw leachate and lyophilized leachate separately.

\section{Materials and Methods}

Collection and Extraction of Plant Material: Tender coconut husk was selected as experimental material. Tender coconuts of moderate weight were collected from local market of Irinjalakuda, Thrissur district and its total weight was taken. Outer husk of the fruit was decorticated, washed and cut into small pieces.Extraction was done in different air tight containers. Approximately $1 \mathrm{~kg}$ of husk was weighed from different tender coconuts, and it was immersed in 5litres of de-aerated water. The husk was hammered well before immersing so as to make the extraction process easier. The extraction process was continued in anaerobic condition for about 30 days.

Lyophilization and Phytochemical Screening : Lyophilization or freeze drying is defined as a stabilizing process in which the sample is frozen followed by a reduction of the water content by sublimation and then by desorption to standards that will no longer allow biological growth or chemical reactions[11].After 30 days of anaerobic leaching, leachate was filtered using Syringe-driven filters $(0.22 \mu)$ and transferred to amber coloured bottles ensuring less air contact. Leachate was then separated into two halves. One half of the leachate was dried using a rotary evaporator and stored in air tight vials. Other half was centrifuged in 5000rpm for 10minutes. The supernatant was filtered and lyophilized in a freeze dryer (Operon Freeze Dryer) and at $4^{\circ} \mathrm{C}$. Qualitative phytochemical analysis of the tender coconut husk leachate was carried out using standard procedures to assess the different types of phytochemical constituents present in the dried leachate. Screenings were done for polyphenols, saponins, flavonoids, alkaloids, tannins and terpenoids and carbohydrates[12-14].

Antimicrobial Susceptibility Test

Microbial Strains: The antimicrobial activities of the raw and lyophilized leachate were tested againstEscherichia coli(MTCC 1652),Lactobacillus plantarum(MTCC 1407), Staphylococcus aureus(MTCC 3160), Klebsiella pneumonia(MTCC 2403),Penicillium sps(MTCC 1995), Aspergillus niger(MTCC 872) and Mucor indicus(MTCC 3318).

Disc Diffusion Assay: Disc diffusion method was used to screen the anti-bacterial activity of tender coconut husk leachate. The plates were prepared by pouring $15 \mathrm{ml}$ of molten sterile nutrient agar media into sterile petri plates. The plates wereallowed to solidify for $5 \mathrm{~min}$. The test microorganisms $10 \mu \mathrm{l}\left(10^{6}\right.$ cells $\left./ \mathrm{ml}\right)$ from overnight broth cultures of bacteria in nutrient broth were seeded into respective plates with medium by spread plate method. Inoculated cultures were allowed to dry. Concentrations of leachate were taken as 1, 2, 5 and $10 \mathrm{mg} / \mathrm{ml}$. Sterilized paper discs of $6 \mathrm{~mm}$ diameter were taken for assay. Prepared sterile paper discs were saturated with tender coconut husk leachate of different concentrations and dried. Saturated discs were then placed on the surface of agar medium of petri plate and allowed to diffuse for 3 minutes. Pre-pared plates were kept for incubation at 37 ${ }^{0} \mathrm{C}$ for $24 \mathrm{hrs}$. Streptomycin $(20 \mu \mathrm{g} / \mathrm{ml})$ discs were used as positive control. DMSO $(100 \mu \mathrm{g} / \mathrm{ml})$ discs were used as negative control. Post-incubation inhibition zones around the extract disc were measured with a transparent ruler in $\mathrm{mm}[15]$. Inhibition value is obtained using the formula,

Inhibition value $=$ Inhibition diameter in $\mathrm{mm}-$ Disk diameter $(6 \mathrm{~mm}) / 2$

The mean and standard deviation of triplicates of various concentrations of plant extracts were calculated and compared with Streptomycin. 
Minimum inhibitory concentration and Minimum bactericidal concentration assays

Minimum Inhibitory Concentration was determined according to Murray's method [16] with slight modifications. Different dilutions of the leachatein increasing concentrationsviz1, 2, 5 and $10 \mathrm{mg} / \mathrm{ml}$ were prepared by dissolving it in DMSO.Standardized suspensions of the test organisms (Escherichia coli, Lactobacillus plantarum, Staphylococcus aureus, and Klebsiella pneumoniae) were inoculated into a series of 96 well microtiter plate including one positive and one negative control. All tubes were incubated at $37^{\circ} \mathrm{C}$ for 24 hours and then examined for growth, by observing the turbidity. The microtiter plate showing the minimum turbidity was noted for MIC. Ten microliters of bacterial culture from the MIC tubes, which did not show any growth was pipetted, and sub cultured onto Nutrient agar, and incubated at $37^{\circ} \mathrm{C}$ for 24 hours. After incubation, the concentration at which there was not a single colony of bacteria was taken as the minimum bactericidal concentration (MBC).

\section{Determination of Antifungal Activity}

Poison Plate Assay: Antifungal activity of tender coconut husk leachate was determined by food-poisoned technique[17] with minor modifications. The plates were prepared by pouring $1 \mathrm{ml}$ of raw/lyophilized leachate in different concentrations (viz.1, 2, 5 and $10 \mathrm{mg} / \mathrm{ml}$ ) in to respective plates. To this $15 \mathrm{ml}$ of molten sterile PDA were poured and allowed to solidify for 5 minutes. After solidification fungus were inoculated using sterile wire loop. The inoculated plates were incubated at $37^{\circ} \mathrm{C}$ for $48 \mathrm{hrs}$. Fluconazole $(20 \mu \mathrm{g} / \mathrm{ml})$ and DMSO $(100 \mu \mathrm{g} /$ $\mathrm{ml}$ ) were used as positive control and negative control respectively.

\section{Result and Discussion}

Phytochemical Screening; The qualitative phytochemical screening test reveals the presence of alkaloids, terpenoids, phenols, tannins and carbohydrates with lyophilized husk leachate. It is noteworthy that the raw samples did not show a positive reaction for alkaloids and terpenoids indicating that these compounds present in the leachate could be heat liable. Carbohydrates were absent in both freeze dried and air dried leachate (Table 1).Phytochemical screening ofC. nucifera conducted by Alvianoet al. has reported that thisplant material is rich in polyphenolic molecules catechin, andepicatechin together with condensed tannins, which conferson its potent antimicrobial properties [18]. Tannins present in the coconut plant extracts possess astringent effect on the mucous membrane. They also form a layer over enamel, thus providing protection against dental caries[19].

\section{Antimicrobial Susceptibility Test}

Disc Diffusion Assay: For the disc diffusion assay we have used two gram positive bacteria (MTCC 3160 \& MTCC 1407) and two gram negative bacteria (MTCC $1652 \&$ (MTCC 2403). In all the experimental trials with raw and lyophilized leachate, the zone of inhibition increased from low to high concentrations (Table 2).It was also observed that both the lyophilized and raw leachate werecomparatively effective in preventing the colonization of gram positive bacteria than gram negative bacteria. At higher concentrations the diameter of zone of inhibition of raw leachate against two gram positive bacteria S.aureus and L.plantarum were found to be 16 and 16.6 millimetres respectively. In the case of gram negative bacteria E.coli and K.pneumoniae the diameter of zone of inhibition decreased to 11.1 and 11.2 millimetres respectively at higher concentrations of raw leachate. The disc diffusion assay also envisage that in all the four concentrations the lyophilized leachate possess a comparative dominance over the raw leachate in preventing both gram positive and negative bacteria. According to the antimicrobial study on coconut husk extract[20], they observed that the antimicrobial activity of husk extract increased with increasing concentration and was found to be more effective against gram-negative than gram- positive organism which was somewhat similar with our results on both lyophilized as well as raw anaerobic husk leachate. Anaerobic leaching may have enhanced the formation of recalcitrant compounds in higher proportions and this may thought to be effective in preventing the colonization of both gram positive and gram negative bacteria tested.

Minimum inhibitory concentration and Minimum bactericidal concentration assays: The average values of Minimum inhibitory concentration and Minimum bactericidal concentration assays are plotted in figure 1. The results show that the minimum inhibitory concentration and minimum bactericidal concentration of gram positive bacteria exhibited much lower values than that of gram negative bacteria. On treatment with raw leachate theaverage MIC of gram positive bacteria Lactobacillus was about $2 \mathrm{mg} / \mathrm{ml}$ followed by S.aureus $(5 \mathrm{mg} / \mathrm{ml})$. In the case of gram negative bacteria E.coli and K.pneumoniae, the average MIC value was about $10 \mathrm{mg} / \mathrm{ml}$ each for unaltered raw leachate. Compared to raw leachate the MIC values of L.plantarum and K.pneumoniae were found to be decreased to $1 \mathrm{mg} / \mathrm{ml}$ and $5 \mathrm{mg} / \mathrm{ml}$ respectively when treated with lyophilized leachate. On the other hand the MIC values of S.aureus and E.coli when treated with lyophilized leachate were found to be more or less similar with raw leachate treatment. The average $\mathrm{MBC}$ values on treatment with raw leachate were found to be $10 \mathrm{mg} / \mathrm{ml}$ 
each for S.aureus and L.plantarum. In the case of E.coli and K.pneumoniae the average $\mathrm{MBC}$ values were $15 \mathrm{mg} /$ $\mathrm{ml}$ and $20 \mathrm{mg} / \mathrm{ml}$ respectively. The average MBC value of lyophilized leachate show marked difference from raw leachate with an average value of $1 \mathrm{mg} / \mathrm{ml}$ against L.plantarum and $10 \mathrm{mg} / \mathrm{ml}$ against K.pneumoniae. The precise mechanism through which the secondary metabolites from plant materials donate to anti-bacterial activity is not clear, though one of the mechanisms suggests that it is the hydrophobicity which helps partition the cell membrane and rendering them more permeable and leaky[21]

\section{Antifungal Activity}

Poison Plate Assay: The anti-fungal activity of raw leachate and lyophilized leachate after 24 and $48 \mathrm{hrs}$ of incubation against Penicillium sps, Aspergillus niger and Mucor indicus was observed. In the case of raw leachate treatment, when the concentration of leachate increases from $1 \mathrm{mg} / \mathrm{ml}$ to $10 \mathrm{mg} / \mathrm{ml}$, we could observe ameasured decrease in the diameter of the fungal colonies in the PDA plate. The maximum inhibition was seen at the concentration $10 \mathrm{mg} / \mathrm{ml}$ and it was almost equal to the extent of $20 \mu \mathrm{g} / \mathrm{ml}$ of fluconazole (positive control). The Penicillium sps,Aspergillus niger and Mucor indicusexhibited almost similar growth inhibition at highest concentrations. The diameter of growth of Aspergillus niger at the highest concentration $(10 \mathrm{mg} / \mathrm{ml})$ was less than the diameter of positive control but in Mucor the diameter of growth at higher concentration was double the value of positive control.The antifungal activity of lyophilized leachate after $24 \mathrm{hrs}$ of incubation against Penicillium sps, Aspergillus niger and Mucor indicus were evaluated using various concentration. In all the three fungal strain tested, there was a concentration dependent growth inhibition. At the highest concentration $(10 \mathrm{mg} / \mathrm{ml})$, leachate was very effective in limiting the growth of Aspergillus niger to a smaller diameter than that of the positive control (flucanazole). The Penicillium sps shows almost similar results that of positive control. TheMucor indicus seems to be less affected even at higher concentrations of lyophilized leachate. In all the trials the fungal growth was proportionately high in negative control plates.

After $48 \mathrm{hrs}$ of incubation the fungus show similar kind of growth inraw and lyophilized leachate containing PDA plates. In the case ofPenicillium sps and Aspergillus nigergrown in raw leachate containing plates the diameter of growth of the colony at highest concentration $(10 \mathrm{mg} /$ $\mathrm{ml}$ ) were less than that of fluconazole. At the highest tested concentration $(10 \mathrm{mg} / \mathrm{ml})$ of lyophilized leachate, Aspergillus nigerand Penicillium sps shows almost similar diameter of growth as that of fluconazole.In the case ofMucor indicus, even at higher concentration $(10 \mathrm{mg} / \mathrm{ml})$ of raw and lyophilized leachate, the diameter of growth was double that of fluconazole showing they are less affected by any of the leachate. After $48 \mathrm{hrs}$ Penicillium sps, Aspergillus nigerand Mucor indicus were grown to the full plate in DMSO (negative) control.

Table 1: Preliminary phytochemical screening of Coconut husk anaerobic leachate.

\begin{tabular}{|c|c|c|c|}
\hline SI.No & Phytochemicals & Raw Leachate & Lyophilized leachate \\
\hline 1 & Alkaloids & - & + \\
\hline 2 & Terpenoids & + & + \\
\hline 3 & Tannins & + & + \\
\hline 4 & Phenols & + \\
\hline 5 & Flavanoids & - & + \\
\hline 6 & Carbohydrates & + \\
\hline
\end{tabular}

(Key: + presence, - absence)

Table 2: Zone of inhibition of tender coconut husk raw and lyophilized leachate against different bacterial strains.

\begin{tabular}{|c|c|c|c|c|c|c|c|c|c|c|}
\hline \multirow{2}{*}{$\begin{array}{l}\text { Test } \\
\text { organisms }\end{array}$} & \multicolumn{5}{|c|}{ Diameter of zone of inhibition ( $\mathrm{mm}$ )Raw leachate } & \multicolumn{5}{|c|}{$\begin{array}{l}\text { Diameter of zone of inhibition }(\mathrm{mm}) \\
\text { lyophilized leachate }\end{array}$} \\
\hline & $1 \mathrm{mg} / \mathrm{ml}$ & $2 \mathrm{mg} / \mathrm{ml}$ & $5 \mathrm{mg} / \mathrm{ml}$ & $10 \mathrm{mg} / \mathrm{ml}$ & $\begin{array}{l}\text { Strepto- } \\
\text { mycin }\end{array}$ & $1 \mathrm{mg} / \mathrm{ml}$ & $2 \mathrm{mg} / \mathrm{ml}$ & $5 \mathrm{mg} / \mathrm{ml}$ & $10 \mathrm{mg} / \mathrm{ml}$ & $\begin{array}{l}\text { Strepto- } \\
\text { mycin }\end{array}$ \\
\hline E.coli & $8.6 \pm 0.5$ & $11.1 \pm 0.2$ & $13.7 \pm 0.5$ & $16 \pm 1$ & $18 \pm 2$ & $8.7 \pm 0.5$ & $11.9 \pm 0.7$ & $15.3 \pm 0.7$ & $20.1 \pm 1$ & $18.8 \pm 0.7$ \\
\hline K.pneumoniae & $9.3 \pm 1$ & $11 \pm 1.7$ & $14.7 \pm 1.1$ & $16.6 \pm 2$ & $18.7 \pm 0.5$ & $9.5 \pm 0.5$ & $12.5 \pm 0.5$ & $16 \pm 1$ & $20.6 \pm 0.7$ & $19.5 \pm 0.5$ \\
\hline L.plantarum & $6.6 \pm 0.4$ & $8.5 \pm 0.5$ & $9.1 \pm 0.2$ & $11.1 \pm 0.1$ & $18.5 \pm 0.5$ & $7.5 \pm 0.5$ & $9.4 \pm 0.7$ & $10.7 \pm 0.2$ & $12.1 \pm 0.4$ & $18.6 \pm 0.4$ \\
\hline S.aureus & $6.4 \pm 0.5$ & $7.3 \pm 0.2$ & $8.1 \pm 0.7$ & $11.2 \pm 0.2$ & $18.1 \pm 1$ & $7 \pm 0.92$ & $8.2 \pm 0.3$ & $9.5 \pm 1$ & $12.2 \pm 0.4$ & $18.2 \pm 0.7$ \\
\hline
\end{tabular}

Note: The control disc used for solvent had no zone of inhibition, so there data was omitted from the above data. Data are represented in the form of mean of three tests $\pm S D$ of the standard group 
Table 3: Antifungal activity of raw and lyophilized leachate observed after $24 \mathrm{hrs}$ of incubation.

\begin{tabular}{l|c|c|c|c|c|c|c|c|c|c|c|c|}
\multirow{2}{*}{$\begin{array}{l}\text { Test } \\
\text { organisms }\end{array}$} & \multicolumn{4}{|c|}{ Diameter of zone of inhibition (mm) } & \multicolumn{5}{c|}{ Diameter of zone of inhibition (mm) } \\
lyophilized leachate
\end{tabular}

Note: Data are represented in the form of mean of three tests $\pm S D$ of the standard group

Table 4: Antifungal activity of raw and lyophilized leachate observed after $48 \mathrm{hrs}$ of incubation.

\begin{tabular}{|c|c|c|c|c|c|c|c|c|c|c|c|c|}
\hline \multirow{2}{*}{ Testorganisms } & \multicolumn{6}{|c|}{$\begin{array}{c}\text { Diameter of zone of inhibition }(\mathrm{mm}) \\
\text { Raw leachate }\end{array}$} & \multicolumn{6}{|c|}{$\begin{array}{l}\text { Diameter of zone of inhibition }(\mathrm{mm}) \\
\text { lyophilized leachate }\end{array}$} \\
\hline & $\begin{array}{c}1 \mathrm{mgl} \\
\mathrm{ml}\end{array}$ & $\begin{array}{c}2 \mathrm{mg} / \\
\mathrm{ml}\end{array}$ & $\begin{array}{c}5 \mathrm{mg} / \\
\mathrm{ml}\end{array}$ & $\begin{array}{c}10 \mathrm{mg} / \\
\mathrm{ml}\end{array}$ & $\begin{array}{l}\text { Flucana- } \\
\text { zole }\end{array}$ & DMSO & $1 \mathrm{mg} / \mathrm{ml}$ & $2 \mathrm{mg} / \mathrm{ml}$ & $5 \mathrm{mg} / \mathrm{ml}$ & $\begin{array}{c}10 \mathrm{mg} / \\
\mathrm{ml}\end{array}$ & $\begin{array}{c}\text { Flucana- } \\
\text { zole }\end{array}$ & DMSO \\
\hline Penicillium sps & $\begin{array}{r}18 \\
\pm 0.9\end{array}$ & $\begin{array}{l}15.4 \\
\pm 0.5\end{array}$ & $\begin{array}{l}12.8 \\
\pm 0.2\end{array}$ & $\begin{array}{r}10.3 \\
\pm 0.5\end{array}$ & $\begin{array}{r}11.3 \\
\pm 1.1\end{array}$ & FG & $\begin{array}{l}18 \\
\pm 1\end{array}$ & $\begin{array}{l}17.5 \\
\pm 1.3\end{array}$ & $\begin{array}{l}12.7 \\
\pm 0.3\end{array}$ & $\begin{array}{r}10.7 \\
\pm 0.6\end{array}$ & $\begin{array}{r}11.8 \\
\pm 0.8\end{array}$ & FG \\
\hline A.niger & $\begin{array}{r}18.5 \\
\pm 0.4 \\
\end{array}$ & $\begin{array}{c}15.6 \\
\pm 1\end{array}$ & $\begin{array}{c}12.2 \\
\pm 1\end{array}$ & $\begin{array}{l}9.9 \\
\pm 1\end{array}$ & $\begin{array}{l}10.5 \\
\pm 0.9\end{array}$ & FG & $\begin{array}{l}18.2 \\
\pm 0.6\end{array}$ & $\begin{array}{c}17.1 \\
\pm 1\end{array}$ & $\begin{array}{r}11.3 \\
\pm 0.5 \\
\end{array}$ & $\begin{array}{l}10.8 \\
\pm 0.7\end{array}$ & $\begin{array}{l}10.5 \\
\pm 0.7\end{array}$ & FG \\
\hline M.indicus & $\begin{array}{r}50.7 \\
\pm 0.6\end{array}$ & $\begin{array}{c}45 \\
\pm 1.1\end{array}$ & $\begin{array}{l}35.3 \\
\pm 1.3\end{array}$ & $\begin{array}{c}28 \\
\pm 0.4\end{array}$ & $\begin{array}{c}11.13 \\
\pm 1\end{array}$ & FG & $\begin{array}{l}62.2 \\
\pm 0.9\end{array}$ & $\begin{array}{l}46.6 \\
\pm 1.1\end{array}$ & $\begin{array}{l}35.6 \\
\pm 0.9\end{array}$ & $\begin{array}{l}29.2 \\
\pm 0.8\end{array}$ & $\begin{array}{r}11.5 \\
\pm 0.6\end{array}$ & FG \\
\hline
\end{tabular}

Note: Data are represented in the form of mean of three tests $\pm S D$ of the standard group. FG: Fully grown.

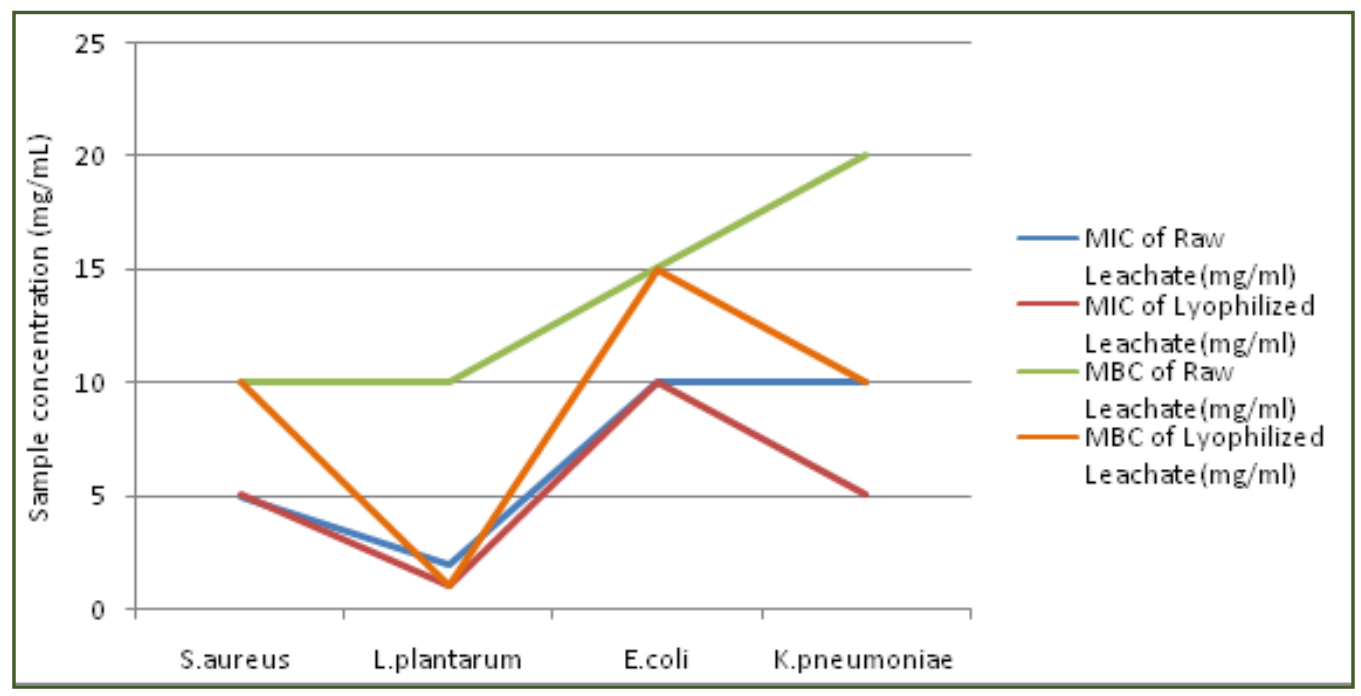

Fig. 1: Showing average MIC and MBC values of raw and lyophilized leachate.

\section{Conclusion}

From this study we could conclude that the anaerobic leachate of tender coconut huskexhibits antimicrobial activity against different pathogenic organisms studied. In all the trials the raw and lyophilized leachate showed very prominent control on microbial growth compared to DMSO (negative) control. The phytochemical analysis revealed the presence of different secondary metabolites in the raw leachate and lyophilized leachate varies. Among these identified metabolites the level of phenolic compounds was reasonably high and this is supposed to be a major factor in limiting the growth of microbes in culture plates. These results help to enhance the possibilities of future studies to isolate potent molecules from coconut husk leachate and 
test for their activity against broad spectrum of multi drug resistant microbes and this may leads to the commercial production of effective and safe antimicrobial products.

\section{Acknowledgement}

The authors are thankful to the Principal, Christ College, Irinjalakuda for the facilities provided for this work. We are thankful to Dr. Leyon Varghese, Assistant Professor Christ College Irinjalakuda, for his constant support and guidance throughout the project.We also acknowledge Dr. Pius K Jacob, HOD, department of zoology for his endless support throughout the project.

\section{Reference}

1. Sharma A, Antibacterial activity of ethanolic extracts of some arid zone plants. Int. J. of Pharm. Tech. Res. 2011;3(1):283-286.

2. Christensen CM, Kaufmann HH, Deterioration of Stored grains by fungi, Annu. Rev. Phytopathol. 1965;3:69-84.

3. Neergard P. In: Seed Pathology, (TheMcMillan Press Ltd. London and Basingatoke) Vol. I. 1977:118-269.

4. Park JW, Kim EK \& Kim YB, Estimation of the daily exposure of Koreans to aflatoxin B1 through food consumption. Food additives and contaminants. 2004; 2(1):70-75.

5. Koirala, P, Kumar S, Yadar BK \&Premarajan KC, Occurrence of Aflatoxin in some of the food and feed in Nepal. Indian Journal of Medical Sciences. 2005; 59: 331-336.

6. Domijan A, Feraica M, Jurjevic Z, Ivil D \&Cvjetkovic B, Fumonisin B1,fumonisin B2, Zearalenone and ochratoxin a contamination of maize in Croatia. Food additives and contaminants.2005;22: 677-680.

7. Calvo MA, Arosemena EL, Shiva C\&Adelantado C,Antimicrobial activity of plant natural extracts and essential oils, Science against microbial pathogens: communicating current research and technological advances. 2011;1:1179-1185.

8. ShirishaRao, BibechanaTimsina\&Varalakshmi KN, Antimicrobial effects of medicinal plants and their comparative cytotoxic effects on HEPG2 cell line. International Journal of Pharmacy and Pharmaceutical Sciences. 2014;6(1): 101-105.

9. Ravindranath $\mathrm{AD}$, Bhosle $\mathrm{S}$, Development of bacterial consortium for coir retting. Journal of Scientific \& Industrial Research. 2000; 59: 140-143.
10. Lima EBC, Sousa CNS, Meneses LN, Ximenes NC, Santos. Junior MA, Vasconcelos GS, Lima NBC, Patrocínio MCA, Macedo D \&Vasconcelos SMM, Cocos nucifera (L.) (Arecaceae): A phytochemical and pharmacological review Brazilian Journal of Medical and Biological Research. 2015;48(11): 953-964.

11. Tushar R. Jadhav and Moon RS, Review on lyophilization technique. World journal of pharmacy and pharmaceutical sciences. 2015;4(5) :1906-1928.

12. Trease GE \& Evans WC, Pharmacology 11thed, (BailliereTindall Ltd., London).1989;60-75.

13. Sofowora A, Medicinal Plants and Traditional Medicines in Africa (Chichester John Wiley \& Sons New York). 1993; 97- 145 .

14. Kokate CK, Purohit AP \&Gokhale SB, Practical Pharmacognosy, 4th ed. (VallabhPrakashan Publishers, New Delhi). 2006; 107-108

15. Bauer AW, Kirby WM, Sherris JC, Turck M. Antibiotic susceptibility by standardized single disk method. American Journal of Clinical Pathology. 1966; 45(4): 493-496.

16. Murray PR, Baron EJ, Pfaller MA, Tenover FC \&Yolken, RH, Manual of Clinical Microbiology, 6th edition. (American Society of Microbiology Press, Washington DC). 1995; 1482 p.

17. Schmitz H, Food poisoned technique. Industrial Engineering Chemical Analyst Education. 1930; 361-363.

18. Alviano WS, Alviano DS, Diniz CG, Antoniolli AR, Alviano CS, Farias LM, et al. In vitro antioxidant potential of medicinal plant extracts and their activities against oral bacteria based on Brazilian folk medicine. Arch Oral Biol. 2008;53:545-52.

19. Prashanth GM, Chandu GN. The effect of mango and neem extract on four organisms causing dental caries: Streptococcus mutans, Streptococcus salivarius, Streptococcus mitis, Streptococcussanguis: An in vitro study. Indian J Dent Res. 2007; 18:148-51

20. Shettigar R, Lala R, Nandvikar NY. Evaluation of antimicrobial activity of coconut husk extract. Annals of Applied Bio-sciences. 2014;1:A23-27.

21. Sikkema J, De Bont AM, Poolman BM. Interaction of cyclichydrocarbons with biological membranes. J BiolChem1994;269:8022-8.

*Corresponding author:

Praveen Krishnakumar, Immunology \& Toxicology Research Lab, Dept. of Zoology, Christ College, Irinjalakuda, Thrissur, Kerala, India. 680125 Phone: +91 09447370509

Email: pvnpraveen1990@gmail.com 